\title{
Contamination of Rhinovirus Seed Pools Revealed in HEp2 Cell Suspension Cultures
}

\author{
By M. S. ROSENTHAL \\ From the Departments of Preventive Medicine and of Medicine, Western Reserve \\ University School of Medicine and University Hospitals, \\ Cleveland, Ohio, U.S.A.
}

(Received 28 September 1964)

\section{SUMMARY}

Two seed pools of rhinovirus were contaminated accidentally at different times with the same virus. This contamination was detected only in certain 'spinner flask' experiments under circumstances which suggested the possibility that a mechanism other than contamination was responsible for the appearance of this virus. Experiments were made to test some of these possible mechanisms, but the results strongly indicated a contamination. The circumstances under which this contamination probably occurred are discussed.

\section{INTRODUCTION}

The rhinoviruses (Andrewes, 1961-62) are a large group of viruses that have many properties of enteroviruses and have been causally associated with common colds (Tyrrell et al. 1960; Bynoe et al. 1961; Hamre \& Procknow, 1961; Reilly et al. 1962; Bloom et al. 1963). Rhinovirus strains have been classified into two subgroups depending on whether they grow only in cultures of human kidney cells ( $H$ strains) or also in monkey kidney cell cultures (M strains). HGP strain of rhinovirus is a prototype of $M$ strains. In an attempt to obtain high-titred seed pools of rhinovirus, HGP was inoculated into HEp2 cell suspension cultures. During these experiments a second virus appeared and displaced the rhinovirus from these cultures. This occurred on four occasions under circumstances which suggested the possibility that a mechanism other than contamination was responsible for the appearance of this second virus. This second virus was called spinner virus because of its association with cell cultures maintained in suspension in 'spinner flasks'. Experiments were made to identify spinner virus and to determine its source. In view of the ever increasing number of recoverable viruses and of laboratories in which multiple agents are under simultaneous study, the experiments that are the subject of this report would seem increasingly pertinent.

\section{METHODS}

Viruses. The viruses used in HEp2 cell suspension experiments are listed in Table 1. Virus 1 was isolated in human embryonic kidney cell cultures in Salisbury, England, from the nasal washings of a patient with a common cold. It was then passed 4 more times in similar cultures and once in Rhesus monkey kidney cell cultures before being sent to this laboratory. Virus 2 was similarly isolated and 
passed twice in human embryonic kidney cell cultures in Salisbury. Viruses 3 and 4 were serologically identified as HGP in England but had a different source or a different passage history from those of viruses 1 and 2. Virus 5 represented the eighth passage in human embryonic kidney cell cultures of virus 2 . Viruses 6 and 7 were originally obtained from Salisbury and adapted to KB cells by $\mathrm{Dr} W . S$. Jordan.

Table 1. Viruses used in experiments with HEp2 cell suspensions

\begin{tabular}{ll}
\multicolumn{1}{c}{ Virus } & \multicolumn{1}{c}{ Obtained from } \\
1. HGP & Dr D. A. J. Tyrrell \\
2. HGP & Dr D. Taylor-Robinson \\
3. HGP & Dr D. Taylor-Robinson \\
4. HGP & Dr D. Taylor-Robinson \\
5. HGP & Dr D. Taylor-Robinson \\
6. HGP & Dr W. S. Jordan \\
7. FEB & Dr W. S. Jordan \\
8. 2060 & Dr H. S. Ginsberg \\
9. Measles & Dr J. F. Enders
\end{tabular}

Supplier's designation
ce 287
cc 803 , KELLY, (33-48), 7-2-61
cc 671, Harrison, 1-30-61
cc 1050, 12-14-16
KELLY, cc 1322, 1-23-62
6th KB, 7-31-62
2nd KB, 7-31-62
TC 816, Group 2, 11-27-58
Edmonston, 29th HK pass

Media. The growth medium used for the propagation of HEp2 cells consisted of Mixture 199 (Morgan, Morton \& Parker, 1950) supplemented with $10 \%$ (v/v) calf serum.

The maintenance medium for the cells was Hanks' balanced salt solution supplemented with $2 \%(\mathrm{v} / \mathrm{v})$ calf serum, $0.25 \%(\mathrm{w} / \mathrm{v})$ lactalbumin hydrolysate, and $0.052 \%(\mathrm{w} / \mathrm{v}) \mathrm{NaHCO}_{3}$. All media contained 100 units of pencillin $\mathrm{G} / \mathrm{ml}$. and $100 \mu \mathrm{g}$. streptomycin $/ \mathrm{ml}$. At monthly intervals kanamycin $(50 \mu \mathrm{g} . / \mathrm{ml}$.) and amphotericin B (2.5 $\mu \mathrm{g} . / \mathrm{ml}$.) were added to both growth medium and maintenance medium.

Cells. The strain of HEp2 cells used was obtained from a commercial source (Microbiological Associates, Inc., Bethesda, Md., U.S.A.) and was maintained in serial culture in $32 \mathrm{oz}$. prescription bottles. Transfer of cells was made by treating with Puck's saline A (Puck, Cieciura \& Fisher, 1957) and then 0.04\% (w/v) trypsin (1/250, Difco) in saline A to detach them from the glass. Test-tube cultures were prepared by the inoculation of screw-capped tubes with approximately 60,000 cells suspended in $0.5 \mathrm{ml}$. growth medium.

In preparing spinner flask cultures, trypsin-treated cells were resuspended in maintenance medium rather than in growth medium and the cell concentration was adjusted to $1 \times 10^{5}$ to $6 \times 10^{5} \mathrm{cells} / \mathrm{ml}$. Although suspended in maintenance medium, the number of cells generally doubled during the first $24 \mathrm{hr}$ of incubation at $33^{\circ}$ but did not increase after this.

Preparation of rabbit antisera. Young male albino rabbits were inoculated (4 to 6 times) intravenously at 7- to 10-day intervals with 3-5 ml. of infectious virus suspension. There were no signs of illness following these inoculations. Rabbits were bled initially and the sera were tested for antibodies before each inoculation after the third. Generally neutralizing antibody titres of 1000 against 100 TCID 50 (signifies $50 \%$ tissue culture infectious doses) of virus were achieved. After three intravenous inoculations one rabbit was given a subcutaneous injection consisting of $1.5 \mathrm{ml}$. of spinner virus with a titre of $10^{8} \mathrm{TCID} 50 / 0.1 \mathrm{ml}$. and $3.5 \mathrm{ml}$. of complete Freund's adjuvant. Serum from this rabbit also achieved maximal titres of 
neutralizing antibody of 1000. Typing antisera for Coxsackie types A1-8, A 10-24 and B1-6, and for echovirus types 29-32 were kindly supplied by $\mathrm{Dr} H$. A. Wenner.

Neutralization tests. Equal volumes of virus suspensions containing 100 TCID 50/ $0.1 \mathrm{ml}$. and two-fold serum dilutions were mixed and incubated for $3 \mathrm{hr}$ at $37^{\circ}$. For each serum dilution $\mathbf{0 . 2} \mathrm{ml}$. of this mixture was inoculated into each of four HEp2 cell tube cultures freshly changed with $1.0 \mathrm{ml}$. maintenance medium. These tubes were incubated for 5 days in a roller wheel at $33^{\circ}$ without changing medium. They were then examined for cytopathic effects and the neutralizing antibody titres were determined. The neutralization tests with spinner virus and antisera specific for poliovirus types 1, 2 and 3, Coxsackie viruses types A 9 and B 1-5, and echoviruses types 1-27 were done by Dr Martha Lepow in Rhesus monkey kidney cell cultures.

Complement-fixation test. Complement-fixation tests were made by a modification of the drop method of Fulton \& Dumbell (1949), with 2.5 units of complement.

Virus titrations. Virus from infected tube cultures consisted of pooled tissueculture medium. Virus from spinner flask cultures was obtained by freezing and thawing the cell suspension $\mathbf{3}$ times and centrifuging to remove cell debris. Virus titrations were done in HEp2 cell tube cultures incubated at $33^{\circ}$ in a roller wheel. Serial 10-fold dilutions of virus were prepared in maintenance medium and $\mathbf{0} \cdot \mathbf{1} \mathrm{ml}$. of each dilution was inoculated into 3 HEp2 cell tube cultures. The cultures were examined for cytopathic effects and the medium changed every $48 \mathrm{hr}$ for a total of 6 days, at which time titrations of spinner virus were discarded. Titrations of rhinovirus were kept for 8 days. On the final day HEp2 cell culture tubes were scored for the presence or absence of cytopathic effects and the $50 \%$ end-point was calculated by the method of Reed \& Muench (1938).

Incubation conditions. Unless otherwise specified, infected tube cultures were incubated at $33^{\circ}$ in a roller wheel and spinner flask cultures at $33^{\circ}$.

Stains. Acridine orange staining was done on coverslip cultures according to the method of Bertalanffy (1958). Haematoxylin and eosin stains were done on cells fixed in Bouin's solution.

Other tests. Chloroform sensitivity tests were done by the method of Feldman \& Wang (1961). Tests of stability at $\mathrm{pH} 5$ and $60^{\circ}$ were done as outlined by Dimmock \& 'Tyrrell (1962). The ability of 5-fluoro-2'-deoxyuridine (FUDR) to inhibit viral replication was determined according to the method of Salzman (1960). Herpes simplex virus and Coxsackie B, Type 3 virus were used as controls in these experiments.

\section{RESULTS}

The experiments with HEp2 cell suspensions were made to determine whether or not the HGP virus would grow to higher titres in suspended cells than in tube cultures. The initial results showed that the titre of virus was higher in spinner flasks of suspended cells and that the cytopathic effect was indistinguishable from that of HGP virus. It was not then apparent that another virus might be responsible for these results. After antisera were prepared against spinner virus, it was found that there was no serological relationship between spinner virus and HGP virus, and that all four of the spinner virus strains were serologically identical. The 
possibility was then explored that spinner virus was a contaminant. In support of this hypothesis was the fact that in each experiment in which spinner virus appeared, the HGP virus used could be traced to either a specific seed pool of virus 1 or a similar pool of virus 2 (Table 1 ). The contamination hypothesis was initially rejected for several reasons. First, the seed pool of virus 1 had been stored before virus 2 was introduced into the laboratory. Secondly, the only virus similar to spinner virus in the laboratory when these pools were in preparation was a stool isolate present only during the formation of the pool of virus 2. An attempt had been made to isolate virus from this stool during the preparation of the pool of virus 1 , but had been unsuccessful. The third reason for initially rejecting the contamination hypothesis was that although the pools of virus 1 and 2 had been inoculated into tube cultures of HEp2 cells on many occasions, spinner virus was not detected. Although spinner virus grows very well in tube cultures, it was exclusively associated with HEp2 cell suspensions.

The possibility was next investigated that the cells might themselves be the source of this virus. Uninfected HEp2 cell suspension cultures were prepared and studied in the same way as infected cultures, but no spinner virus was detected. Material from frozen and thawed uninfected cells was passed serially into suspension cell cultures but no virus appeared. Then the possibility was tested that a virus infection was necessary to 'induce' the appearance of spinner virus which was latent in the HEp2 cells. This was done by inoculating viruses 3 to 9 (Table 1) into HEp2 cell suspensions. Material from these frozen and thawed infected cultures was then passed serially into suspension cell cultures; but spinner virus was not detected.

The HGP seed pools associated with spinner virus were then considered as a possible source. This was tested by an experiment to see whether treatment with spinner antiserum could 'cure' of spinner virus contamination a sample of a seed pool of HGP virus known to be associated with spinner virus in HEp2 cell suspension cultures. A sample of an appropriate HGP seed pool was selected and passaged serially 3 times at its terminal dilution in HEp2 cell tube cultures in the presence of sufficient spinner antiserum to neutralize 1000 TCID 50 of virus. Treated virus was then tested for spinner virus by serial passage into HEp2 cell suspension cultures, but no spinner virus was found. A sample of treated virus was passaged serially 10 more times without spinner antiserum in HEp2 cell tube cultures. When this virus was tested for spinner virus in suspension cell cultures, none was found. This result was inconclusive, however, because untreated samples of virus from pools associated with spinner virus were frequently also negative when similarly tested.

Another aspect of the contamination hypothesis of the origin of spinner virus was studied as follows. Two pools of HGP virus were deliberately contaminated with spinner virus, one with the virus at its terminal dilution and one at $0.5 \log _{10}$ unit beyond the terminal dilution. These contaminated pools were then serially passaged in HEp2 cell tube cultures. After three passages, spinner virus was detected in all tubes of this experiment. In the light of this result, the repeated failure to detect spinner virus in tube cultures inoculated with pools known to be associated with spinner virus was interpreted as evidence against the contamination hypothesis.

Experiments to characterize and identify spinner virus were then made in the hope that they would give data from which other hypotheses of its origin might be 
derived. Some of these data (summarized in Table 2) indicated that spinner virus was an enterovirus. Dr Martha Lepow attempted unsuccessfully to identify spinner virus with antisera specific for the enterovirus serotypes likely to be encountered in tissue cultures. Subsequent tests with antisera specific for the Coxsackie A types not likely to be isolated in tissue culture also failed to identify spinner virus.

Table 2. Properties of spinner virus and HGP virus

1. Contains RNA

2. Ether and chloroform resistant

3. Enterovirus-like cytopathic effect in human and monkey cells

4. Cytopathic effects and titre in tube cultures enhanced by rolling

5. Stable indefinitely at $-70^{\circ}$

6. Stable for 10 days at $20-23^{\circ}$

7. Stable at $\mathrm{pH} 5 \cdot 0$

8. Stable at $60^{\circ}$ for $1 \mathrm{hr}$ in $\mathrm{M}-\mathrm{MgCl}_{2}$

+ indicates property present; - indicates property absent.

The only other hypothesis about the origin of spinner virus which was considered was that it represented a mutant or variant of HGP virus which was selected by suspension cell culture conditions. Attempts to show a serological relationship between spinner virus and HGP virus in complement-fixation tests were unsuccessful. Because of this and the many other important biological differences between spinner virus and HGP virus summarized in Table 2 the mutation hypothesis seemed untenable and the contamination hypothesis more probable.

The stool isolate mentioned previously which had been present during the formation of the seed pool of virus 2 (Table 1 ) was then reconsidered as a source of this contamination. Virus from this stool was tested with spinner antiserum and was found to be serologically identical with spinner virus. Dr Martha Lepow then again attempted to identify spinner virus with enterovirus antisera and was able to show that spinner virus and the stool isolate were strains of Coxsackie $\mathbf{B}$ virus, type 5 . These findings strongly indicated that the stool isolate was the source of spinner virus and that the HGP virus seed pools associated with spinner virus had been contaminated with it.

The stool isolate had been present in the laboratory during the preparation of the contaminated seed pool of virus 2 (Table 1). An isolation attempt in Rhesus monkey kidney cell cultures from this stool had been present during the preparation of the contaminated seed pool of virus 1 (Table 1 ) but at that time no virus was isolated. Rhesus monkey kidney cell cultures used in this isolation attempt were markedly affected by a simian virus infection and it is possible that stool virus was present and multiplying but a cytopathic effect not detected. It has not been possible retrospectively to identify any other opportunity for the demonstrated stool virus contamination of the virus 1 seed pool to have occurred. A subsequent attempt to isolate virus from this stool inlboth HEp2 cells and Rhesus monkey kidney cell was successful only in the HEp2 cells, which indicates that they were more sensitive to this virus than Rhesus monkey kidney cells under the conditions used. It has not been possible to explain the initial failure to identify spinner virus as Coxsackie B, type 5. Review of the protocol of this experiment suggested that the 
technique used had influenced the results: the spinner virus used was titrated in stationary tubes and the test itself was incubated in a roller wheel. Since the titre of spinner virus was usually $\mathbf{1 0}$-fold higher in rotated tubes than in stationary tubes, it is possible that too much virus had been inoculated for the antiserum dilution used.

All the techniques used in the laboratory were reviewed in an attempt to determine how this contamination had occurred. It seemed most likely that it occurred during the process of changing medium in infected tube cultures. During this process the screw cap of the culture tube is held in the fifth finger of the pipetting hand while the tube itself is removed from the cap and re-inserted into it with the other hand. If the lip of a tube containing virus should touch the hand near to the screw cap being held, some virus might be deposited there and survive to be transferred to another tube which also touched the contaminated place on the hand. An experiment was made to see whether such contamination might occur even in the face of flaming the culture tubes, as was routinely done. A pipette was dipped into a suspension of spinner virus with a concentration of $10^{5} \mathrm{TCID} \mathrm{50/0} \cdot 1 \mathrm{ml}$. and the tip of the pipette then touched to the hand near where screw caps are ordinarily held. Twelve uninfected HEp2 cell tube cultures were in turn uncapped and the lip of the tube touched to the deliberately contaminated area of the hand. The first six of these tubes were flamed in the usual way and the last six were not flamed. All twelve of the tubes showed spinner virus cytopathic effect within $48 \mathrm{hr}$.

\section{DISCUSSION}

Contaminations in tissue culture and virology laboratories are probably not rare events. The contamination of tissue cells in continuous culture with Mycoplasma and cells of other lines has been the subject of several reports (Rothfels et al. 1959; Clausen \& Syverton, 1962; Defendi et al. 1960; Robinson, Wichelhausen \& Roizman, 1956; Holmgren \& Campbell, 1960). Laboratory-acquired infections with viruses, including the Coxsackie viruses (Shaw, Melnick \& Curnen, 1950; Shelokov \& Habel, 1957; Bell \& Meis, 1959) have been described, and the two individuals who worked with spinner virus in this laboratory each developed significant rises in neutralizing antibody titre against this virus. These infections were clinically inapparent, as were some of the infections described by Lerner, Klein \& Finland (1960).

A review of the literature for the last 10 years revealed only one report (Siegel, 1956) of a laboratory contamination with a virus that had features similar to the contamination reported here. An important similarity is that the contaminating virus shared several biological properties with the virus that was contaminated. It was because of this fact that the contamination went unrecognized for some time.

The contaminant Coxsackie B, type 5 virus described here likewise had several biological properties very similar to those of the rhinoviruses. Another factor which contributed to its non-recognition was that the contaminant was present in only trace amounts, so that its occurrence was relatively infrequent and under such circumstances as to suggest another mechanism for its origin. The exclusive association of spinner virus with 'spinner flask' experiments seems largely to have been due to the relatively large volumes of undiluted contaminated rhinovirus pools used in 
such experiments. It is estimated from the frequency with which spinner virus was detected and the total volume of the contaminated pools, that only $20 \%$ of $5-\mathrm{ml}$. samples from these pools would have contained an infective dose of the contaminant. Similarly, only $0 \cdot 4 \%$ of $0.1 \mathrm{ml}$. samples (the volume routinely used in tube culture experiments) would have included an infective dose of spinner virus. It seems likely that because its cytopathic effect is grossly indistinguishable from that of HGP virus the appearance of spinner virus in an occasional tube culture would not have been noted. It is equally likely that, were it not for the 'spinner flask' experiments, the contamination would not have been detected at all.

The contamination reported here serves to re-emphasize the constant attention necessary to prevent such occurrences. It is not possible to be certain exactly how this particular contamination occurred; it may have happened when medium was being changed. This possibility is supported by the results of the experiment to contaminate culture tubes from the hand, which suggest that flaming the lips of culture tubes as done routinely in the laboratory would have been insufficient to prevent contamination. Methods designed to destroy a contaminant such as the one described here seem likely to fail often and are no substitute for keeping potential contaminants from the work area altogether.

The excellent technical assistance of Mrs Sophie Koenig is gratefully acknowledged. This investigation was conducted under the auspices of the Commission on Acute Respiratory Diseases, Armed Forces Epidemiological Board, and was supported in part by the Office of The Surgeon General, Department of the Army, and by grants from the Robert Hamilton Bishop, Jr. Endowment Fund and the Republic Steel Corporation.

\section{REFERENCES}

ANDREwes, C. H. (1961-62). The taxonomic position of common cold viruses and some others. Yale J. Biol. \& Med. 34, 200.

BeLl, J. F. \& MeIs, A. (1959). Pericarditis in infection due to Coxsackie virus group B type 3. New England J. Med. 261, 126.

BertalanfFy, L. von (1958). A rapid screening method for the detection of cancer cells. Cancer, 11, 873.

Bloom, H. H., Forsyth, B. R., Johnson, K. M. \& Chanock, R. M. (1963). Relationship of rhinovirus infection to mild upper respiratory disease. I. Results of a survey in young adults and children. J. Amer. med. Ass. 186, 38.

Bynoe, M. L., Hobson, D., Horner, J., Kipps, A., Schild, G. C. \& Tyrrell, D. A. J. (1961). Inoculation of human volunteers with a strain of virus isolated from a common cold. Lancet, i, 1194.

Clausen, J. J. \& Syverton, J. T. (1962). Comparative chromosomal study of 31 cultured mammalian cell lines. J. nat. Cancer Inst. 28, 117.

Defendi, V., Billingham, R. E., Silvers, W. K. \& Moorhead, P. (1960). Immunological and karyological criteria for identification of cell lines. J. nat. Cancer Inst. 25, 359.

Dimmock, N. J. \& Tyrrell, D. A. J. (1962). Physiochemical properties of some viruses isolated from common colds (rhinoviruses). Lancet, ii, 536.

Feldman, H. A. \& Wang, S. S. (1961). Sensitivity of various viruses to chloroform. Proc. Soc. exp. Biol., N.Y. 106, 736.

Fulton, F. \& Dumbell, K. R. (1949). The serological comparison of strains of influenza virus. J. gen. Microbiol. 3, 97.

Hamre, D. \& Procknow, J. J. (1961). Viruses isolated from natural common colds in the U.S.A. Brit. med. J. 11, 1382. 
Holmgren, N. B. \& Campbenl, W. E. Jr. (1960). Tissue cell culture contamination in relation to bacterial pleuropneumonia-like organisms-L form conversion. J. Bact. 79, 869.

LeRNER, A. M., KLEIN, J. O. \& FinLAND, M. (1960). A laboratory outbreak of infections with Coxsackie virus group A, type 9. New England J. Med. 263, 1302.

Morgan, J. F., Morton, H. J. \& Parker, R. C. (1950). Nutrition of animal cells in tissue cultures. I. Initial studies on a synthetic medium. Proc. Soc. exp. Biol. Med. 73, 1.

Puck, T. T., Ciecrura, S. J. \& Fisher, H. W. (1957). Clonal growth in vitro of human cells with fibroblastic morphology. J. exp. Med. 106, 145.

REED, L. J. \& MUENCH, H. (1938). A simple method of estimating fifty per cent end points. Am. J. Hyg. 27, 493.

Reilly, C. M., Hoch, S. M., Stokes, J. JR., McClemland, L., Hamparian, V. V., Ketler, A. \& Hilleman, M. R. (1962). Clinical and laboratory findings in cases of respiratory illness caused by coryzaviruses. Ann. int. Med. 57, 515.

Robinson, L. B., Wichelatudsen, R. H. \& Roizman, B. (1956). Contamination of human cell cultures by pleuropneumonia-like organisms. Science, 124, 1147 .

Rothfels, K. H., Axelrod, A. A., Siminovitch, L., McCullock, E. A. \& Parker, R. C. (1959). The origin of altered cell lines from mouse, monkey and man as indicated by chromosome and transplantation studies. Proc. 3rd Canad. Cancer Conf. pp. 189-214. New York: Academic Press Inc.

Salzman, N. P. (1960). The rate of formation of vaccinia deoxyribonucleic acid and vaccinia virus. Virology, 10, 150.

Shaw, E. W., Melnick, J. L. \& Curnen, E. C. (1950). Infection of laboratory workers with Coxsackie viruses. Ann. int. Med. 33, 32.

Shelokov, A. \& Habel, K. (1957). Viremia in Coxsackie B meningitis. Proc. Soc. exp. Biol., N.Y. 94, 782.

SiEgeL, B. V. (1956). Contaminant filterable agent derived from a human wart. $J$. invest. Derm. 27, 379.

Tyrreli, D. A. J., Bynoe, M. L., Hitchcock, G., Pereira, H. G., Andrewes, C. H. \& Parsons, R. (1960). Some virus isolations from common colds. Lancet, $\mathbf{i}, 235$. 